\title{
Las muchas caras de la naturaleza humana
}

\author{
Guillermo Murray Tortarolo
}

1

o cabe duda de que los seres humanos somos una cosa extraordinaria. Cada cerebro es un sistema solar único y cada cultura una galaxia. Cuando nos juntamos todos se forma un universo casi infinito de singularidades sociales, filosóficas y morales. Este numero de la Revista Digital Universitaria es una celebración a esta diversidad. Comencemos por las miradas a la ciencia moderna que nos ofrece la sección Varietas en este número septiembre-octubre.

Que mejor manera de pensar a la pluralidad humana que con el mismo lenguaje. La última vez que revisé hay mas de 7,000 lenguajes existentes y, como nos platican Aurora Martínez y colaboradores en su artículo "Lenguaje: instrumento del desarrollo humano", no se trata únicamente de una herramienta de comunicación, sino también del núcleo de nuestra forma de aprender y comprender el mundo que nos rodea. Cuando aprendemos a hablar, también aprendemos a pensar.

Este mismo lenguaje tiene muchas formas de expresión: hablada, cantada y por supuesto escrita..., pero qué te parece la que escribimos sobre nosotros mismos: los tatuajes. Ese es justamente el tema de otro artículo, titulado "La tinta y la bata blanca" en que Alain Massieu y Rocío García nos platican desde problemas cutáneos hasta cambios en las relaciones médicopaciente por los tatuajes de "no resucitar", los tatuajes han venido a revolucionar el trabajo médico y ponen en la mesa problemas éticos, sociales y morales del mundo moderno.

Hablando de problemas morales y sociales, ¿te has preguntado por qué sucede la delincuencia?, y más importante aún ¿es acaso toda la delincuencia igual en la mente del criminal? En el artículo "Crimen y economía: un acercamiento a la teoría de Gary Becker", Marcos Silva nos cuenta los postulados de un premio Nobel de economía para explicarnos que los criminales asignan valor a sus crímenes. En otras palabras, se genera una burbuja submoral en la que se asignan distintos costos y beneficios a los distintos tipos de maldad.

Dol: http://doi.org/10.22201/cuaieed.16076079e.2021.22.5.0 
Pero la injusticia humana no sólo toma formas de criminales, se trata también de la represión y acallamiento de ciertos grupos sociales. Posiblemente ningún grupo ha sido más agredido en este aspecto que las mujeres. Su lucha ha sido larga y difícil para comenzar a crear un mundo más equitativo entre géneros - aunque aún distamos de tenerlo-. En su artículo "Género y democracia", Jorge Platas nos cuenta la historia de la lucha democrática de las mujeres en el mundo y en México, para contextualizar el panorama actual de nuestro país.

La otra gran forma del lenguaje, una que rompe barreras idiomáticas son las matemáticas: ya se trate de la dinámica de los tsunamis o para ver los orígenes del universo, ellas están presenten en todas partes. Y justamente en este número abordamos esos dos temas. En primer lugar, tenemos a Yuri Skiba quien nos cuenta qué hace tan destructivas a estas enormes olas. En su artículo "Dinámica de olas del tsunami", podemos explorar la mezcla entre compresión de olas y crestas explosivas que dan como resultado este catastrófico fenómeno.

Por último, las matemáticas nos permiten incluso ver los orígenes del universo. Y no hay máquina más maravillosa que se haya construido a partir de esta idea, que el Gran Colisionador de Hadrones. Como nos cuenta Lizardo Valencia en su artículo "El Gran Colisionador de Hadrones: una maravilla del mundo moderno", se trata de una verdadera proeza de la humanidad. Esta máquina cubre casi $30 \mathrm{~km}^{2}$ y es el hogar de al menos 3,000 científicos, todos ellos centrados en tener aunque sea un suspiro de lo que fue el origen de nuestro universo.

Pero, así como cada día entendemos mejor lo macroscópico, también nos hemos vuelto mejores en ver lo microscópico. En particular hemos puesto nuestra atención en las cosas diminutas que nos enferman y nos matan: los virus y las bacterias. En este número de la RDu tenemos tres artículos destinados a nuestros microorganismos. En primer lugar, tenemos una bella historia de la lucha por el descubrimiento de un grupo muy interesante de virus, llamados bacteriófagos. Estos tienen la curiosa tendencia a comerse a las bacterias y su descubrimiento fue una batalla mental entre dos científicos. Como nos cuentan Juan y Martín Talavera en su artículo "Bacteriófagos, los virus comebacterias: historia de dos mentes científicas" algunos asumen que el responsable de este descubrimiento fue Félix d'Herelle y otros lo atribuyen a Frederick W. Twort. ¿Quieres saber quién fue el verdadero descubridor? Entonces lee este artículo.

No podríamos tocar el tema de los microorganismos en el día de hoy, si no hablamos del temible, terrible y eterno covid-19. A casi dos años del inicio de esta pandemia, cada vez comprendemos mejor al virus y estamos mejor capacitados para detectarlo y frenarlo. En primer lugar y como nos cuentan Jorge Melendez-Zajgla, Bertha Rueda-Zarazúa, Alfredo Garcia-Venzor y Vilma Maldonado en el artículo "crisprCas: la nueva herramienta para diagnosticar enfermedades infecciosas", tenemos tecnologías novedosas de edición e identificación de ADN. Éstas le dieron el premio nobel a Jennifer Doudna y Emmanuelle Charpentier en 2020 y están siendo utilizadas para abaratar y facilitar la detección de covid-19. 
Para terminar con esta sección, Benjamín García y Adela Rodríguez nos cuentan que son exactamente los famosos anticuerpos. En su artículo "Aplicaciones médicas de los anticuerpos", nos platican a detalle que hacen estas increíbles moléculas y cómo su estudio y entendimiento está revolucionando la medicina moderna. Una lectura esencial para estos tiempos de pandemia.

Pero nuestra RDU no sería la misma sin su perspicaz visión sobre los procesos universitarios. En la sección Continuum Educativo tenemos dos artículos sumamente interesantes y contrastantes. Por un lado, Cynthia Fuentes nos narra la falta de dirección en el financiamiento de la educación superior en México. Tal parece que nuestras universidades van dando tumbos, a base de prueba y error para descubrir qué funciona y qué no. Su artículo "Financiamiento de la educación superior: el panorama mexicano" es una crítica sumamente fundamentada a la necesidad de planes estratégicos a nivel nacional.

Las mismas estrategias han faltado para hacer frente a la pandemia, y la educación virtual también parece estar dando tumbos. Por suerte tenemos la visión de Ana Copado y José Osorio en su artículo "Clase a distancia en tiempos de pandemia: recomendaciones pedagógicas". Aquí nos ofrecen cuatro sencillos pasos para crear clases exitosas, interesantes y sobre todo pedagógicas. No más choro mareador durante dos horas frente a la pantalla, necesitamos actividades claras, un diálogo activo y retroalimentación constante para que esto funcione.

Los retos educativos en la pandemia también se han manifestado en otros aspectos de la universidad. En la sección Universidades contamos con la respuesta a dos grandes preguntas frente a la pandemia: ¿nos está yendo mejor como educadores?, y ipuedo viajar al extranjero para estudiar bajo las circunstancias actuales? La primera pregunta la contesta nuestra propia Mercedes de Agüero y su equipo de colaboradores, en su artículo "Los retos educativos durante la pandemia de covID-19: segunda encuesta a profesoras y profesores de la uNAM". De acuerdo con sus hallazgos, los profesores se sientes mejor calificados y más tranquilos para dar clases virtuales, pero lamentablemente aún no se ve un cambio en las herramientas pedagógicas utilizadas, lo cual sigue siendo una limitante para la enseñanza.

La segunda pregunta la contestan Josefina Guerrero y colaboradores, quienes nos narran las experiencias de distintos estudiantes y docentes a quienes la pandemia los encontró en el extranjero. Su artículo "De pandemias, movilidad al extranjero y resiliencia: perspectivas estudiantiles y docentes" presenta una visión alentadora sobre el intercambio académico y hasta nos anima a pensar en hacerlo, pese a las circunstancias.

Y este número termina por todo lo alto con un increíble video. En la sección más visual de todas, Caleidoscopio, tenemos a Laura Sánchez, nuestra super estrella de la educación virtual quien nos cuenta que significa ser una EduTuber —el sueño de muchos... Bueno, al menos mío seguro que sí-. A lo mejor has oído de Laura por su canal de YouTube mvz Laura Sánchez y si no, ¿qué esperas? Tiene toda clase de tips increíbles para la educación a distancia: desde cómo configurar tu audio y video, hasta 
como generar muros interactivos y poner stickers para tus clases. Y en este número, nos cuenta su experiencia y las claves del éxito para llegar a tener miles de seguidores.

Aquí me despido de ustedes, esperando que disfruten este número tanto como yo. No cabe duda de que tiene condimentos para todos los gustos y para todos esos sistemas solares interiores. Que este universo de saberes los enriquezca cada día y los ayude a pasar esta pandemia interminable.

\section{Guillermo Murray-Tortarolo}

Es investigador asociado $\mathrm{C}$ en el Instituto de Investigaciones en Ecosistemas y Sustentabilidad de la Universidad Nacional Autónoma de México (UNAM). Su tema principal de trabajo es la investigación ecológica a distintas escalas espaciotemporales. Le interesa entender los impactos del cambio y la variación climática sobre distintos procesos ecológicos y agronómicos de México y el mundo. También tiene un profundo interés y pasión por la divulgación de la ciencia y por su enseñanza.

\section{Cómo citar este artículo}

* Murray-Tortarolo, Guillermo. (2021, septiembre-octubre). Las muchas caras de la naturaleza humana. Revista Digital Universitaria (RDU), 22(5). http://doi.org/10.22201/ cuaieed.16076079e.2021.22.5.0 